\title{
ON THE FORMATION OF OIL AND GAS TERMS IN CHINESE BY THE COMPOSITION METHOD
}

\section{Madina Farkhod Kizi Nizomiddinova}

Teacher, Department Of “Chinese Philology”, Faculty Of “Chinese Studies”, Tashkent State University Of Oriental Studies

\section{ABSTRACT}

Nowadays, the development of language is associated with the formation of different spheres. In particular, the lexical layer of the Chinese oil and gas industry is evolving in accordance with the rules of language development. In this article, one of the methods of making oil and gas terms is the compositional (syntactic) method, its features.

KEYWORDS: - Word formation, composition method, attributive, copulative, verb-object, verb-complement, subject-predicative.

\section{INTRODUCTION}

In oil and gas terminology, the number of singlesyllable simple and artificial terms is very small, but complex compound terms and compound terms are widely used. Therefore, it is important to study the features of the construction of oil and gas terms.

This article is devoted to the fact that one of the methods of word formation of oil and gas terms is made by the composition method.

Composition (lat. compositio - to compose) - to add a word [1, p. 51]

Add a word (add a base) - create new words by adding several (two or more) words or bases in a single word. The main word-forming tool in word-addition is the addition of words or bases
[2, p. 28]

\section{THE MAIN FINDINGS AND RESULTS}

In Chinese, words formed by the composition method are more common than other methods. V.M. Solntsev also states in his research that the method of word addition leads, the method of affixation is the second method, and gives grounds for calling the method of word addition the "syntactic method" [3, pp. 80-81].

There are 5 ways to make a composition:

1. 偏正式 piānzhèng shì attributive model;

2. 并列式 bìngliè shì copulative model;

3. 动宾式 dòngbīn shì verb-object model;

4. 补充式 bǔchōng shì verb-complementary model; 
CURRENT RESEARCH JOURNAL OF PHILOLOGICAL SCIENCES 2(5): 109-

112, May 2021 DOI: https://doi.org/10.37547/philological-crjps-02-05-23

ISSN 2767-3758

(C)2021 Master Journals

Crossref do: 81 Google

Accepted25 $5^{\text {th }}$ May, 2021 \& Published 31 ${ }^{\text {th }}$ May, 2021

5. 主谓式 zhǔwèishì subject-predicative model.

Below we consider them one by one:

Two or more syllable terms can be formed through an attributive model. Using this model, terms belonging to the word family are created. In the attributive model, the first component defines the second component, thereby creating a determinant-definite relationship in them. Let's look at their construction using the following formulas, where the components of the joints come with the letters $A, B, S, D$, the dependence comes with the sign " $\rightarrow$ ":

\section{A- >V (Two-syllable terms):}

钻杆 zuàngăn "drill pipe, drill rod">钻 “drilling” + 杆 “pipe”

浊流 zhuóliú “turbid flow">浊»лойқа» + 流 "flow"

重力 zhònglì "gravity">重》оғир» + 力 “power"

远场 yuănchăng "long zone">远 “long" + 场 "zone"

圆井 yuánjǐng “Round well”> 圆 “Round" + 井 "well"

纵倾 zòngqīng "longitudinal slope">纵 "longitudinal" + 倾 "slope"

As can be seen from the above examples, joint $A$ defines joint $V$, i.e., joint $A$ is subordinate to joint V.

\section{V- >A (Two-syllable terms):}

钻速 zuànsù "rotation speed">钻 “to rotate" + 速 "speed"

井底 jǐngdǐ “well under, bottom”>井 “well” + 速 "under, bottom"

油田 yóutián “oil mine”> 油 “oil”+ 田 “mine”

Here, joint $V$ represents joint $A$, i.e., joint $V$ is subordinate to joint $A$.

\section{A- , VS (Three-syllable terms):}

白石蜡 bái shílà “white paraffin”>白 “white” + 石蜡 "paraffin”

电脱盐 diàn tuōyán "electric desalination">电 "electric” + 脱盐 "desalination”

张应力 zhāng yìnglì "tensile stress"> 张 "tensile" + 应力 "stress"

\section{AV- >S (Three-syllable terms):}

安全阀 ānquán fá “valve protection”>安全 "protection" + 阀 "valve”

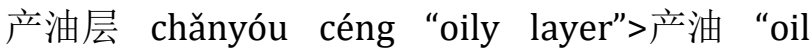
production"+ 层 “layer"

润滑油 rùnhuá yóu "lubrication oil”>润滑 "to lubricate" + 油 "oil”

燃料油 ránliào yóu “fuel oil”>燃料 "fuel” + 油 "oil"

套管头 tàoguăn tóu “reinforcing pipe head">套管 "reinforcing pipe" + 头 "head".

\section{AV— >CD (Four-syllable terms):}

地热勘探 dìrè kāntàn "geothermal search">地热 internal heating of the earth + 勘探 “to search”

沉积盖层 chénjī gàicéng "sedimentary coating">沉积 “sediment” + 盖层 “coating, peel”

航空汽油 hángkōng qìyóu "aviation gasoline”>航空 “aviation” + 汽油 "gasoline”

\section{AVC— >DE (Five-syllable terms):}

试验室分析 shìyànshì fēnxī "laboratory analysis”>试验室 “laboratory” + 分析 “analysis”

水化学测量 shuǐhuàxué cèliáng "Hydrochemical examination">水化学 “Hydrochemical” + 测量 "to examine"

\section{AVCD— >EF (Six-syllable terms):}

地球物理勘探 dìqiúwùlǐ kāntàn "geophysical 
CURRENT RESEARCH JOURNAL OF PHILOLOGICAL SCIENCES 2(5): 109-

112, May 2021 DOI: https://doi.org/10.37547/philological-crjps-02-05-23

ISSN 2767-3758

(C)2021 Master Journals

\section{Crossref do) 81 Google}

Accepted25 $5^{\text {th }}$ May, 2021 \& Published 31 ${ }^{\text {th }}$ May, 2021

search">地球物理 “geophysical” + 勘探 “to search".

In the copulative model, the components of artificial words are mutually equal, mainly synonymous, antonymous, cohesive words are involved. The following are examples of word formation based on this model:

Combination of synonymous components:

褶皱 zhězhòu “twist, fold” > 裮 “twist” + 皱 “fold”

闭合 bìhé “close, lock"> 闭 “lock" + 合 “close”

孔隙 kǒngxì "porous" > 孔 "porous" + 隙 “crack"

坍塌 tāntā “to fall” > 坡 “to fall” + 塌 “йиқилмоқ, қуламоқ"

浸渍 jìnzì “sink” > 浸 “to sink” + 渍 “to get wet”

Combination of antonymic components:

升沉 shēngchén "rise and fall” > 升 “to rise" + 沉

"to decrese"

While the first component of words formed by the verb-object model represents action, the second component is a word belonging to the noun phrase that represents an object. Through this model, words belonging to the noun, verb group are formed. The following terms created by this model include:

钻头 zuàntóu "coating (drill" > 钻 "to drill” + 头 "head, upper part"

修井 xiūjǐng "well repair" > 修 “to repair" + 井 "well"

拖力 tuōlì "gravity" > 修 “to pull” + 井 "power"

探进 tànjìn “search well” > 探 “to search" + 进 "well"

压力 yālì "pressure" > 压 "squeeze, press" + 力 "power"

给料 gěiliào "transfer, push (e.g. raw material)" >

给 "squeeze, press" + 料 "raw materials"
加工 jiāgōng "recycleing” > 加 “increase” + 工 "industry"

吸气 xīqì "recycleing” > 吸 “increase" + 气 "gas"

接地 jiēdì "grounding" > 接 “to accept" + 地 "ground".

While the first component of the words formed by the verb-complement model forms words denoting the action of the verb phrase, the second component is the complement of the verb. Through this model, words belonging mainly to the verb family are formed.

While the first component of words formed by the subject-predicative model are words denoting an object belonging to the noun phrase, the second component is in the form of an owner-cut relationship.

\section{Conclusion}

To sum up, the role of internal sources in the formation of oil and gas terms in the Chinese language is invaluable. Terms formed by the composition method are more important than the affixation method. From the terms created on the basis of 5 models of this type, the terms created by the attributive model lead. It turned out that most of the oil and gas terms created by the attributive model had three or four syllables. Among the terms generated by the copulative model of the composition method, it was found that the method of mainly equal bonding is more likely to be formed using a combination of synonymous components. It turned out that the oil and gas terms formed on the verb-object model of the composition method are mainly in the form (verb + noun = verb).

\section{ReFERENCES}

1. Hojiev A. (2002) Annotated Dictionary of Linguistic Terms. - Tashkent: National Encyclopedia of Uzbekistan. - p. 51. 
CURRENT RESEARCH JOURNAL OF PHILOLOGICAL SCIENCES 2(5): 109-

112, May 2021 DOI: https://doi.org/10.37547/philological-crjps-02-05-23

ISSN 2767-3758

(C)2021 Master Journals

crossref do) 81 Google

Accepted25 ${ }^{\text {th }}$ May, 2021 \& Published 31 ${ }^{\text {th }}$ May, 2021

(А.Хожиев.

127-129).

терминларининг изохли луғати. -

Тошкент: Ўзбекистон Миллий

Энциклопедияси, 2002. - Б. 51.)

2. Xashimova S. (2018) Word formation in Chinese. - Tashkent: Sharq. - p. 28. (Хашимова С. Хитой тилида сўз ясалиши. - Тошкент: Шарқ, 2018. - Б. 28.)

3. V.M. Solntsev. (1951) Essays on Modern Chinese. - Moscow: IMO Publishing House. - pp. 80-81. (Солнцев B.M. Очерки по современному китайскому языку. - Москва: Издательство ИМО, 1951. - C. 80-81.)

4. 才 否 顾英利. 化工名词. 北京 : 科学出版社, 2017年.

5. 叶庆全. 油气田开常用名词解释. 北京: 石油工业出版社, 2009年. - 488页.

6. 张抗. 对非常规油气某些术语的讨论 // «Natural Gas Technology». 天然气技术与经济, 2013. №4. 第3-7页.

7. 潘腾杨、威聂超飞.

国内外油气储运术语标准对比分析 // 《标准科学》 (Standard Science). - 北京, 2014. №7. 第68-71页.

8. 石油名词.

北京: 石油名词审定委员会, 1994年.

9. Rasuljanovna, I. N. (2019). Lacunas Occurance In Semantic Fields Of Chinese And Uzbek Languages. International Journal of Scientific \& Technology Research, 8(11), 1998-2001.

10. Ismatullayeva, N. R. (2020). Expression of somatic physionimistic lacunas in Chinese and Uzbek languages. In Наука и инновации в XXI веке: актуальные вопросы, открытия и достижения (pp. 